\title{
Some Quantitative Studies of a Relationship Between Hardness Salts and Organic Matters in Natural Waters
}

\author{
Suren Sargsyan \\ Institute of Hydroecology and Ichthyology of the Scientific Center of Zoology and Hydroecology, National Academy of Science of Republic \\ of Armenia, Yerevan, Armenia
}

\section{Email address:}

Sarsur@bk.ru

\section{To cite this article:}

Suren Sargsyan. Some Quantitative Studies of a Relationship Between Hardness Salts and Organic Matters in Natural Waters. Journal of Water Resources and Ocean Science. Vol. 6, No. 5, 2017, pp. 61-64. doi: 10.11648/j.wros.20170605.11

Received: September 4, 2017; Accepted: September 22, 2017; Published: October 13, 2017

\begin{abstract}
It has been revealed the organic matter association with hardness salts in natural water samples by increasing the concentration of hardness salts and determining permanganate oxidation value before and after salt settling. In these waters, after the association of about $34 \%$ of organic matters with salts, a further increase in salt concentration doesn't lead to an essential rise in the portion of organic matter association.
\end{abstract}

Keywords: Natural Waters, Hardness Salts, Salt Settling, Organic Matters, Association

\section{Introduction}

As it's known, permanganate oxidation (PO) value is an integral indicator of organic matter content in non-heavily polluted natural waters [1]. It mainly characterizes organic matter content in water and partly describes the content of mineral salts which are able to be oxidized by potassium permanganate. In case of high content of mineral salts, for instance $\mathrm{Fe}^{2+}>0.2 \mathrm{mg} / \mathrm{l}, \mathrm{Mn}^{2+}>0.5 \mathrm{mg} / \mathrm{l}$ and so forth, their impact on PO degree should be taken into consideration, which means it's necessary to determine their content in water samples in advance and recalculate PO value. For separating the impact of salts on PO value, in the previous investigation, an experiment was conducted to reveal the integral portion of salts in PO value by determining PO value before and after the settling of salts in water samples [2, 3]. In the experiment, the water quality was successfully assessed due to the low hardness and comparatively low PO degree of the water samples. Nevertheless, in some further experiments in waters with the high content of hardness salts, high PO values (caused by salts) determined by this method forced us to more punctiliously and purposefully investigate a possible relationship between hardness salts and organic matters in waters. It's necessary to mention that a question regarding how organic matters in water are associated with hardness salts hasn't been completely studied. At the same time, most of metals (firstly di- and trivalent) form dissolved organic complexes with humic and fulvic acids [4-9].

For partially clarifying the aformentioned question, a possible relationship between hardness salts and organic matters in waters was investigated by artificially raising the hardness of natural water samples and determining PO value before and after the settling of salts.

\section{Method}

\subsection{Sample Collection}

Table 1. Location of the investigated observation sites in the aquatic systems.

\begin{tabular}{ll}
\hline No & Sampling site location \\
\hline 1 & Hrazdan river source \\
2 & Lake Akhpara \\
3 & Hrazdan river site located in the upstream from Bjni village \\
4 & Hrazdan river site located in the downstream from Bjni village \\
5 & Marmarik river downstream \\
6 & Hrazdan river site located in the downstream from the confluence \\
7 & with the Marmarik river \\
8 & Hrazdan river site located in Getamej village \\
9 & Hrazdan river site located in Arzni village \\
10 & Arazdan river downstream \\
11 & Yeghegis river midstream \\
12 & Vardenis river source \\
\hline
\end{tabular}


Water samples were taken from the 9 observation sites (Nos 1-9) in the Hrazdan river catchment basin in June, 2015. For model experiments, water samples collected from the Arpa-Sevan tunnel (No 10), the Yeghegis (No 11) and Vardenis (No 12) rivers, which had low water hardness, were considered (Table 1).

\subsection{Sample Preparation}

The hardness of the model water samples was increased by the following technique: $40 \mathrm{mg}$ of each of $\mathrm{Ca}\left(\mathrm{NO}_{3}\right)_{2}$ and $\mathrm{MgSO}_{4}, 25 \mathrm{mg}$ of $\mathrm{Ca}\left(\mathrm{NO}_{3}\right)_{2}, 50 \mathrm{mg}$ of $\mathrm{MgSO}_{4}$ were added to each $100 \mathrm{ml}$ of water sample Nos 10,11 and 12 respectively in the first experiment, and 2 times more contents of the mentioned salts $(80 \mathrm{mg}, 50 \mathrm{mg}$ and $100 \mathrm{mg}$ ) were added to each $100 \mathrm{ml}$ of the corresponding water samples in the second experiment.

\subsection{Sample Analyses}

Water $\mathrm{pH}$ was measured by " $\mathrm{pH}-121$ " laboratory analyzer. The total hardness of water was determined by the 2 methods: well-known complexometric method and salt settling method recommended in our previous investigation $[3,10]$. Permanganate oxidation (PO) value in water was determined by the Kubel method [1]. It was determined firstly in the freshly taken water samples, then, after the settling of salts, in $50 \mathrm{ml}$ of upper liquid layer and $50 \mathrm{ml}$ of lower liquid layer including settled salts. The reliability factor $(F)$ of the study results was calculated according to the Plakhinski method [11].

\section{Result}

The results of the $\mathrm{pH}$, hardness and PO studies in the observation sites of the Hrazdan river catchment basin are given in Table 2. $\mathrm{pH}$ values in the waters mainly varied between 8.0 and 8.9. The only strong difference $(\mathrm{pH}=7.5)$ were registered in the downstream of the Marmarik river (before its confluence with the Hrazdan river). As shown in Table 2, total hardness according to the Hrazdan river flow until its confluence with the Marmarik river (Nos 1-5) gradually decreased from $5.6 \mathrm{meq} / 1$ to $2.2 \mathrm{meq} / 1$ due to river self-purification and sedimentation processes, and then, after the confluence, increased, reaching $6.1 \mathrm{meq} / \mathrm{l}$. The results of the PO study showed that PO values were always lower in the water samples after the settling of salts than in the water samples before the settling of salts. For each observation site, the observation of this PO value difference recalculated by percentage showed a highlited regularity: the higher the water hardness, the lower the PO values in the water samples after the settling of salts (Table 2). Such a relationship between these 2 parameters may also indicate about the following logical association: some part of organic matters in natural waters is bound to hardness salts, and in case of settling of salts, organic matters bound to them also settle [12].

Table 2. $p H$, hardness and PO values in the water samples taken from the Hrazdan river catchment basin.

\begin{tabular}{lllllll}
\hline No & $\mathbf{p H}$ & $\begin{array}{l}\text { Hardness } \\
(\mathbf{m e q} / \mathbf{l})\end{array}$ & $\begin{array}{l}\text { PO value before salt } \\
\text { settling (mgO/l) }\end{array}$ & $\begin{array}{l}\text { PO value after salt } \\
\text { settling (mgO/l) }\end{array}$ & $\begin{array}{l}\text { PO value decrease level } \\
\text { after salt settling (\%) }\end{array}$ & \begin{tabular}{c}
$\mathbf{F}^{*}$ \\
\hline
\end{tabular} \\
\hline 1 & 8.9 & 5.6 & 3.2 & 2.60 & 18.7 & 6.0 \\
2 & 8.8 & 5.3 & 4.0 & 3.12 & 22.0 & 8.8 \\
3 & 8.3 & 4.1 & 1.4 & 1.10 & 21.4 & 3.3 \\
4 & 8.0 & 4.1 & 2.2 & 1.86 & 15.4 & 3.4 \\
5 & 7.5 & 2.2 & 2.7 & 2.40 & 11.1 & 3.2 \\
6 & 8.0 & 3.0 & 2.7 & 2.38 & 11.9 & 3.0 \\
7 & 8.1 & 4.4 & 1.9 & 1.61 & 15.3 & 2.9 \\
8 & 8.5 & 5.5 & 1.6 & 1.20 & 25.0 & 4.0 \\
9 & 8.1 & 6.1 & 3.0 & 1.87 & 37.6 & 11.3 \\
\hline
\end{tabular}

reliability coefficient of difference of mean PO values before and after salt settling

The results of the PO study in the natural water samples with artificially increased hardness are given in Table 3, which shows that an artificial increase (multiple times) in the hardness of the 3 natural water samples (Nos 10-12) didn't significantly affect primary PO values, which was expectable. However, after adding $40 \mathrm{mg}$ of each of $\mathrm{Ca}\left(\mathrm{NO}_{3}\right)_{2}$ and $\mathrm{MgSO}_{4}$ to the natural water sample No 10 , the determination of PO value in the upper liquid layers after the settling of salts showed a decrease in PO value by about $39 \%$, but the extra addition of of two times more quantities of the same hardness salts increased this parameter by only $2 \%$, and it became $41 \%$.
Such a result was registered by adding only $25 \mathrm{mg}$ and 50 $\mathrm{mg}$ of $\mathrm{Ca}\left(\mathrm{NO}_{3}\right)_{2}$ to the natural water sample No 11 . In the first and second cases, PO value in the upper liquid layers after the settling of salts was decreased by $33.3 \%$ and $34.2 \%$ respectively.

Such dynamics was also registered in case of addition of only $50 \mathrm{mg}$ and $100 \mathrm{mg}$ of $\mathrm{MgSO}_{4}$ to the natural water sample No 12. PO value in the desalinated water sample, compared to that in the water sample before desalination, decreased by $29.4 \%$ and $32.4 \%$ in the first and second cases respectively (Table 3 ). 
Table 3. Dynamics of changes in $P O$ values in the natural water samples with artifically increased hardness.

\begin{tabular}{|c|c|c|c|c|c|c|c|}
\hline No & Natural water sample & $\begin{array}{l}\text { Hardness } \\
\text { (meq/l) }\end{array}$ & $\begin{array}{l}\text { PO value before salt } \\
\text { settling (mgO/l) }\end{array}$ & $\begin{array}{l}\text { PO value after salt } \\
\text { settling (mgO/l) }\end{array}$ & $\begin{array}{l}\text { PO value decrease level } \\
\text { after salt settling }(\%)\end{array}$ & $\begin{array}{l}\text { PO value in } \\
\text { sediment }\end{array}$ & $\mathbf{F}^{*}$ \\
\hline \multirow{3}{*}{10} & Without salt addition & 0.9 & 2.05 & 1.92 & 6.3 & 2.20 & 2.8 \\
\hline & $\begin{array}{l}\text { Addition of } 40 \mathrm{mg} \text { of each of } \\
\mathrm{CaNO}_{2} \text { and } \mathrm{MgSO}_{4}\end{array}$ & 7.6 & 2.10 & 1.28 & 39.0 & 3.04 & 17.6 \\
\hline & $\begin{array}{l}\text { Addition of } 80 \mathrm{mg} \text { of each of } \\
\mathrm{CaNO}_{2} \text { and } \mathrm{MgSO}_{4}\end{array}$ & 15.1 & 2.20 & 1.30 & 41.0 & 3.10 & 18.0 \\
\hline \multirow{3}{*}{11} & Without salt addition & 0.9 & 1.90 & 1.77 & 6.8 & 2.10 & 3.3 \\
\hline & Addition of $25 \mathrm{mg}$ of $\mathrm{Ca}\left(\mathrm{NO}_{3}\right)_{2}$ & 5.1 & 2.10 & 1.40 & 33.3 & 2.70 & 13.0 \\
\hline & Addition of $50 \mathrm{mg}$ of $\mathrm{Ca}\left(\mathrm{NO}_{3}\right)_{2}$ & 10.1 & 2.10 & 1.38 & 34.2 & 2.80 & 14.0 \\
\hline \multirow{3}{*}{12} & Without salt addition & 1.0 & 1.76 & 1.64 & 6.8 & 1.90 & 2.6 \\
\hline & Addition of $50 \mathrm{mg}$ of $\mathrm{MgSO}_{4}$ & 5.4 & 1.80 & 1.27 & 29.4 & 2.25 & 9.8 \\
\hline & Addition of $100 \mathrm{mg}$ of $\mathrm{MgSO}_{4}$ & 10.6 & 1.85 & 1.25 & 32.4 & 2.50 & 12.5 \\
\hline
\end{tabular}

reliability coefficient of difference of PO values in the upper liquid layers and sediment of natural water samples

\section{Discussion}

It's very interesting and important that in all the 3 experiments of this series, PO value in the upper liquid layers of the desalinated water samples, compared to that in the water sample before desalination, decreased almost as much as it in lower water layers including settled salts increased.

The same experiments were conducted in distilled water to show precisely that an aforementioned decrease and increase in PO values weren't conditioned by the oxidation of hardness salts, but were a result of changes in organic matter content in the mentioned volumes. The addition of salts to distilled water didn't practically affect PO value. After the settling of salts, PO values in the upper water layers and the lower water layers including settled salts weren't practically different. It's possible to state that $\mathrm{Ca}^{2+}$ and $\mathrm{Mg}^{2+}$, which were applied, didn't affect $\mathrm{PO}$ value even at high concentrations.

Thus, the results of the study have shown that in parallel with an increase in the content of hardness salts in natural waters, a decrease in organic matter content in the upper liquid layers of water samples after the settling of salts is conditioned by the association of organic matters with these salts. As a result, PO value in the upper liquid layers of the desalinated water samples decreases as much as it in the lower liquid layers (associated with salts) increases.

Moreover, only some part of organic matters is bound to salts since increased salt concentration raises organic matter content associated with salts up to certain limit. If all the content of organic matters available for association is bound to salts, even multiple times increase in salt content will not practically lead to the association of rest organic matters, which is probably due to its specific and complex composition.

Moreover, it became possible to associate salts and settle averagely around $34 \%$ of organic matter content by increasing the concentration of salts in the 3 natural water samples having low hardness (Table 3).

For the experimental proving of this supposition, model experiments on the basis of 3 natural water samples having low hardness $(\leq 1.0 \mathrm{meq} / \mathrm{l})$ were run, during which, water hardness was artificially raised by applying the different combination of hardness salts. The obtained results showed that $\mathrm{PO}$ value in the 3 natural water samples after the settling of salts decreased by $6.3 \%$ in the sample No 10 and $6.8 \%$ in the sample Nos 11 and 12 (Table 2). In this case, if we consider that this small decrease was only conditioned by the settling of organic matters, then it can be thought that this decrease doesn't have essential influence on total PO value, and in such cases, the investigation method recommended in the previously published article is justified [2]. Nevertheless, according to the experimental results, the method isn't desirable to apply for water samples with high hardness, and especially if they also have high PO values.

\section{Conclusion}

1. The results of the study have shown a highlighted regularity: the higher the water hardness, the lower the PO value in a natural water sample after salt settling which may indicate that some part of organic matters in natural waters is associated with hardness salts, and in case of the settling of salts, organic matters associated with them also settles. This conclusion was experimentally proved by the example of 3 natural water samples having low hardness.

2. By artificially increasing the hardness of the 3 natural water samples by multiple times, it became possible to associate organic matters with salts and settle $29-41 \%$ of its content. Organic matter content wasn't fully settled which is probably conditioned by the specifics of organic matters.

3. The results of the study have shown that it's possible to reveal organic matter association with salts by measuring PO value by the hardness salt settling method recommended in our previous investigations.

\section{References}

[1] Lure U. U. (edtd.). Uniform methods for the analysis of waters. Izd. 2. Moscow, "Khimia", 1973, 376 pp. (In Russian).

[2] Sargsyan S. A. Investigation of hardness and permanganate oxidation value in water systems by a new methodical approach. Modern Environmental Science and Engineering, 1(1), 2015, pp. 49-52. 
[3] Sargsyan S. A. A method for determining water hardness. Patent of RA, № 2823 A, G01N 33/00, registered in 25.03.2014 (In Armenian).

[4] Chemical composition of water: major (prevailing) components (In Russian).

[5] Available at: http://all-about-water.ru/chemicalcomposition.php

[6] Kondrateva L. M., Shunkova N. N., Andreeva D. V. Effect of heavy metal ions on the structure of bacteriobenthos from different habitats in the Amur river. Vladimir Ya. Levanidov's Biennial Memorial Meetings, 5, 2011, pp. 239-246 (In Russian).

[7] Linnik P. N., Nabivanec B. I. Forms of the migration of metals in fresh surface waters. Leningrad, "Gidrometeoizdat", 1986 (In Russian).

[8] Ostrovskaya E. V., Brekhovskikh V. F., Volkova Z. V., Monakhov S. K., Kurapov A. A., Kocharyan A. G. Heavy metals in the system "Volga Delta-North Caspian". The South of Russia: ecology, development, 4, 2008, pp. 156-163 (In Russian).

[9] Sieliechi J. M., Lartiges B. S., Ndi S. K., Kamga R., Kayem G. J. Mobilisation of heavy metals from natural pozzolan by humic acid: Implications for water and environment. International Journal of Environmental Protection, 2, 2012, pp. 11-15. Wang-Wang T., Guang-Ming Z., Ji-Lai G., Jie L., Piao X., Chang Zh., Bin-Bin H. Impact of humic/fulvic acid on the removal of heavy metals from aqueous solutions using nanomaterials: A review. Science for the Total Environment 468-469, 2014, pp. 1014-1027.

[10] Lure U. U. (edtd.). Uniform methods for the analysis of waters. Izd. 1. Moscow, "Khimia", 1971, 375 pp. (In Russian).

[11] Plakhinski N. A. Biometrics. Moscow, "MGU”, 1970, 367 pp. (In Russian).

[12] Sargsyan S. A. A method for determining and exploring the distribution of organic matters and hardness salts in natural waters. Applied Water Science, 2016, pp. 1-6. DOI: 10.1007/s13201-016-0511-3. 